\title{
The Harmonization of Contract Law through European Rules: a Law and Economics Perspective
}

\section{Fernando Gómez Pomar}

School of Law

Universitat Pompeu Fabra 


\begin{abstract}
${ }^{*}$
This paper aims to present some preliminary ideas about the potential benefits and costs arising from the process of European Contract Law harmonization for the functioning of the existing national Contract Laws, and in the end, for the welfare of European societies. Some of those benefits and costs will essentially be illustrations of some relevant generic features of a legal harmonization process abstractly considered, whereas others will apply specifically to the current process under way in Europe and affecting European Contract Law. Section 1 serves as introduction, Section 2 would first present and then examine the potential benefits of the harmonization process, while Section 3 will deal with the reverse side, that is, with some of the potential risks, broadly understood, of the harmonization endeavor. Section 4 briefly concludes.
\end{abstract}

Title: The Harmonization of Contract Law through European Rules: a Law and Economics Perspective

Título: La harmonización del derecho europeo de contratos desde la perspectiva del análisis económico del derecho

Keywords: European Contract Law; Harmonization; Law and Economics

Palabras clave: Derecho europeo de contratos; harmonización; análisis económico del derecho

\title{
Summary
}

\section{Introduction}

2. Some plausible benefits from adopting harmonizing instruments of European Contract Law 2.1. Efficiency in economic relationships

2.2. Reducing transaction costs in cross-border trade

2.3. Economies of scale in legal reform

3. The potential costs of adopting harmonizing instruments on European Contract Law

3.1. Heterogeneity of preferences and economic conditions

3.2. Process goes beyond mere codification, for better and for worse

3.3. A complex game in which legislator interacts with contracting parties and Courts

3.4. The lack of clear behavioral models on contracting behavior

3.5. The insufficient use of empirical knowledge on contracting behavior

\section{Conclusions}

\section{References}

\footnotetext{
* I am grateful to participants at seminars on the role of (internationally) mandatory rules in a multi-level European system of private law at the University of Amsterdam, and on the future of European contract law -the Draft Common Frame of Reference- at ERA for helpful comments and suggestions. All remaining errors are, of course, my own.
} 


\section{Introduction}

One of the most visible developments of Private Law, and specially Contract Law, in recent years, has been the emergence of different processes focused on an increased Europeanization of the substantive rules and principles, well beyond the more traditional -albeit still importantissues of choice of Law and enforcement of judicial and arbitral decisions against one contracting party situated in a different jurisdiction. Obviously, the legislative activity of the EU, most notably with respect to important transactions involving consumers, has played an important role in providing additional focus, impetus and concreteness to those processes. The Commission Communication on European Contract Law and the revision of the Acquis ${ }^{1}$ has formalized, to some extent at least, the existing plethora of initiatives and developments. In addition to the evaluation, review, and reformulation of significant portions of the consumer Acquis, the process has been focused around the formulation of a Common Frame of Reference (CFR) that would condense principles, rules, and terms to organize and give coherence to the legal materials -the Acquis among them, but not exclusively- in the field of contracts. It would also serve to inspire the interpretation and application of existing Law, including national Laws of the European countries, and eventually give rise to a new body of Law in the field of contracts, most likely as a non-binding instrument.

The existing process, thus, seems to be one of creation of the framework for a more or less distant stage of legislative decision-making. And whatever the legal nature of the final outcome of the process, possibly in the form of a new piece of legislation (even if optional or non-binding as a legal instrument), it seems undeniable that the set of principles and rules contained in the CFR involves a general approach to the legal regulation of contracts in Europe, containing both mandatory and default rules that aspire to constitute at least an important part of the legal environment of contracting in economic and social environment of contemporary Europe.

The present paper tries to present some preliminary ideas about the potential benefits and costs arising from this process for the functioning of the existing Contract Laws in the different European countries, and in the end, for the welfare of European societies. Some of those benefits and costs will essentially be illustrations of some relevant generic features of a legal harmonization process in abstractly considered, whereas others will apply specifically to the current process under way in Europe and affecting European Contract Law. Section 2 would first present and briefly examine the potential benefits, while Section 3 will deal with the reverse side, that is, with some of the potential risks, broadly understood, of the harmonization endeavor. Section 4 briefly concludes.

\footnotetext{
1 Communication from the Commission to the European Parliament and the Council of 11 October 2004, on European Contract Law and the revision of the acquis: the way forward, COM (2004) 651.
} 


\section{Some plausible benefits from adopting harmonizing instruments on European Contract Law}

I do not purport to examine exhaustively the potential benefits of the current process set in motion to prepare and adopt new bodies of Law in Europe affecting the area of contractual activity of firms and individuals. Nor I will examine in detail the draft CFR to comment on the advantages of the specific normative solutions proposed. I will limit myself to briefly review the beneficial effects that, in theory, may ensue from a process such as the existing one, without committing to a normative evaluation about the already available outcomes -even if still in draft form- of the current enterprise, and whether it has exploited all available opportunities to maximize those potentially positive effects. I will mention three of these: To improve the way in which the existing Contract Law is affecting the efficiency of contractual interactions, to reduce transaction costs from diversity in the legal regulation of contracts, and to achieve economics of scale in legal reform. I do not include here any kind of redistributive ideal, given that the broad scope of application of Contract Law (not just B2C, but also B2B, or C2C), and the broad differences across countries in the factors affecting the outcomes of such policies, in all likelihood prevent the pursuit of consistent redistributive policies at this level of generality ${ }^{2}$.

\footnotetext{
2 The statement in the text does not imply either of the following propositions. On the one hand, that distributive concerns are not relevant for the design and operation of rules of Private Law. On the other, that at lower levels of generality in the scope of Contract Law rules, distributive policies constitute a general appealing alternative for legal policy in Private Law, in terms of being both normatively convincing and feasible as an overarching goal. I think both assertions generally tend to be wrong. On the first, see Juan José GANUZA and Fernando GómEZ, "Realistic Standards: Optimal Negligence with Limited Liability", Journal of Legal Studies (2008) forthcoming, showing how distributive questions -levels of wealth, and distribution thereof- are relevant for the optimal design of Tort liability. On the second, showing how distributive policies face important informational and other problems in design when one tries to adequately pursue them in consumer markets, or in areas of voluntary interactions in which parties may react to policies by rearranging the terms of trade: Fernando GómEZ, "The Unfair Commercial Practices Directive: A Law and Economics Perspective", European Review of Contract Law (2006), p. 9; Fernando GóMEZ, "Contract Law and Economic Welfare: A View from Law and Economics", Stefan GRUNDMANN (ed.), Constitutional Values and European Contract Law, Kluwer (2008) (forthcoming). Again, the latter proposition does not constitute a kind of impossibility theorem showing that redistribution through Contract Law rules will always be moot, in the way that some prominent scholars think: See, Louis KAPLOW and Steven SHAVELL, "Why the Legal System is Less Efficient Than the Income Tax in Redistributing Income", 23 Journal of Legal Studies (1994), p. 667; Louis KAPLOW and Steven SHAVELL, "Should Legal Rules Favor the Poor? Clarifying the Role of Legal Rules and the Income Tax in Redistributing Income", 29 Journal of Legal Studies (2000), p. 821.
}

There are, in fact, environments in which a particular Contract Law rule can have desirable efficiency properties and, at the same time, induce desirable redistribution of welfare in favor of consumers: See, Alexander STREMITZER, "Opportunistic Termination", Working Paper, University of Bonn, Department of Economics (2007), available at SSRN: http:/ / ssrn.com/abstract=989557 in the case of termination rights for consumers when sellers have market power. The proposition I advance is just one of scepticism about the feasibility of general and global redistribution policies through Contract Law rules, given the complexity of factors that influence the efficiency and the distributive effects of those rules, that do not seem amenable to an across-the-board policy for a wide variety of environments. In fact, this is what makes things complicated for Contract Law: if redistribution were always impossible or undesirable, or if it were an easy task, life would be much simpler for those devoted to the academic analysis of Contract Law. 


\subsection{Efficiency in economic relationships}

From a Law and Economics perspective, it seems logical to start with efficiency as a plausible advantage of a process of legal reform in the area of contracts. Contractual interactions are one of the major sources of economic and social development, as they provide the main channel for cooperation among individuals and for exploiting the undeniable benefits of division of labor, and trade among agents with divergent valuations. In complex and developed societies as the European ones, the Law, and specifically the Law of Contracts, provides one of the most important mechanisms to foster the adequate functioning of contracting through the creation of incentives for cooperative behavior inside contractual relationships, and the removal of incentives for non-cooperative attitudes.

The Law, however, may not get its task right, and may not contain the legal solutions that actually maximize the joint welfare of the contracting parties, by creating the wrong incentives, or by interfering with the incentive mechanisms set out by the interested parties themselves in their arrangements. Contract Law scholars have for centuries, and Law and Economics scholars for decades, criticized inadequate solutions adopted by Contract Law to achieve the desirable outcomes in a given set of contractual circumstances.

It is true that Contract Law is not the only force working towards efficiency -that the surplus from the voluntary interaction becomes as large as technologically or otherwise materially feasible, that the surplus is maximized, to use the mathematical jargon economists tend to favour. Competition in the markets for goods and services seems at least as important for achieving this goal. But not even the most devout believers in the benefits of competitive markets think that competitive equilibrium will happen without some help from legal rules, and also from Contract Law rules.

First, because many contractual interactions in real life take place outside the realm of environments that can become competitive markets: the problems of information and incompleteness of the terms of the interaction are so relevant that we cannot expect something remotely similar to a competitive market. And then, general rules in Contract law sanctioning duress, fraud and other informational deficiencies, and regulating contract enforcement and remedies for breach of contract have to take the lead.

Second, because in areas in which competitive markets are feasible, the problems that may afflict them (informational problems, for instance) are common with contractual environments, and thus may be subject to rules and regulatory measures that resemble those in Contract Law -a sort of leading role of contractual solutions in areas of market regulation.

European Laws probably differ widely on how they perform in these respects. It is also safe to assume that even the most refined Contract Law system, the one working most effectively towards improving the contractual surplus of the parties, avoiding at the same time negative external effects, is still not working optimally and presents shortcomings, maybe even significant ones. 
Is it possible that legal reform may be able to unearth existing deficiencies and offer improvements in legal rules, institutional arrangements, and strategies for legal decision-makers that can enhance the welfare of contracting parties? The answer is, naturally, yes, it is possible. Is it also possible that such legal reform is set in motion and carried out substantially at the European level, that is, at a level that in terms of abstraction and geographical scope lies beyond the current systems of Contract Law, that to this day remain mainly national in their design and scope? Again, the answer is yes. It is possible to improve the efficiency of the existing performance of Contract Law national systems through reform measures, even comprehensive ones, which can take place at the European level.

The core issue, of course, is how to do it properly. To design and apply an optimal system of Contract Law that improves matters and, at the same time, does not interfere with the healthy effects of competitive markets, and with the appropriate incentives of the existing rules and institutions, is not an easy task. For instance, how comprehensive the European led outcomes should be? How much variation should we allow in the solutions and outcomes, due to the unquestionable fact that still the single Member States are, all in all, more homogeneous in terms of preferences and relevant factors affecting the legal solutions, than the European ensemble? What level of detail do we think optimal for the legislative solutions, and what role do we leave to Courts and other adjudicators to develop more specific measures?

Just the type of questions that are not readily answerable in this respect are good indications of the magnitude of the task of optimal law-making at this European level and on contractual matters. The theoretical point remains, however: it may be possible to enhance the efficiency of Contract Law as a working legal instrument in Europe, but if we do not think we can do it at the European level, better not waste resources in a process that will not improve the welfare situation of the individuals and firms that are subject to Contract Law in their economic and other interactions.

An additional source of concern about the success in this difficult task lies in the set of incentives that the leading actors in the European process would face to get things right. May be the experts and the politicians that may endorse the outcomes of the drafting efforts share a common and powerful concern for the well-being of European societies, and this provides sufficient incentives. From an economic perspective, one should be prima facie alert at the expression of pure otherregarding interests and preferences. Typically, politicians, but also other agents, public and private, act for a variety of motivating factors, combining the own interest with genuine altruistic and other-regarding preferences. Taken as granted a given level of social welfare interest in European politicians, the more they will be politically and immediately rewarded or punished by their decisions and choices, the more incentives they have for getting things right, that is, for satisfying the preferences of their constituents. At the European level, this set of incentives based on political rewards and punishments works less effectively, and with substantially less immediacy, that at the local and national levels. Therefore, one would expect, all things being equal, less successful outcomes in terms of responding to the preferences of European citizens. 
The current process, it is true, has been up to now substantially dominated by the academic legal experts. And these, for better and for worse, do not face the political incentives that politicians, even at the more distant European sphere, have to live with. How this affects the overall set of incentives for the task would require further analysis, but it is clear that they do not look, at least initially, necessarily more promising than at the level of the individual Member State.

\subsection{Reducing transaction costs in cross-border trade}

The language of removing barriers that hamper the smooth functioning of the internal market in goods and services, looms large in the reasons provided by European legislation to justify the introduction of common or harmonized rules in very different areas, consumer Law and Contract Law among them. The idea that harmonized rules in Contract Law serves to promote the European internal market can be understood as comprising two different elements or perspectives. One refers to the reduction for firms of the costs of doing business in various national markets: If a firm plans to launch a product in several Member States, the costs of compliance with legal constraints are obviously higher, may be even much higher, in the presence of different legal requirements than with a single set of legal conditions for the business campaign. For instance, this dimension of reducing to firm's costs of doing business, associated with harmonization has been underlined with respect to several Directives in the field of consumer Law. ${ }^{3}$

It can be cogently argued, however, that legal and regulatory diversity will not disappear as a consequence of a harmonizing legal body in Contract Law, let alone common notions and principles. The reason would lie primarily in the fact that even if the Law in the books may become the same in the different Member States, the Law in action would still definitely differ widely: Courts and other adjudicators, legal procedure, legal culture and environment in general will remain national, and thus would not allow a dramatic reduction in diversity costs for firms doing business Europe-wide. Moreover, the need to adapt to local market conditions will always impose costs on cross-border activities by firms, and thus the extra cost of more complex legal compliance in various jurisdictions would be close to negligible.

The second element in the picture, often with unappreciated relevance, has to do with the consumer. In fact, some argue that consumer perceptions about legal and other uncertainties and shortcomings of transacting over the national borders are the key building blocks of the barriers to cross-border trade, and thus the crucial factor affecting the implementation of the internal market through regulatory and legal harmonization ${ }^{4}$. The crucial obstacles to trade and contracting across the boundaries of legal and regulatory jurisdictions would thus essentially be

\footnotetext{
3 See, Stefan GrundmanN, “European Contract Law of What Colour?”, (2005) 2 European Review of Contract Law, p. 184; Karl RiesENHUbER, "System and Principles of EC Contract Law", (2005) 3 European Review of Contract Law, p. 303.

4 See, Hugh Collins, "EC Regulation of Unfair Commercial Practices", in Hugh Collins (ed.), The Forthcoming EC Directive on Unfair Commercial Practices, Kluwer (2003), p. 3.
} 
demand-driven, that is, those that consumers view, perhaps mistakenly, as negatively influencing their decision to contract cross-border.

In any case, it seems hard to deny that legal complexity and variety entail some level of transaction costs for firms contemplating commercial activities in the different areas covered by the diverse legal and regulatory regimes, and for consumers who could become customers of those goods and services. Lawyers primarily, but also other legal experts, are specialized professionals who obtain quasi-rents from, among others, the task of assessing, managing and minimizing the risks associated with such diversity. The phenomenon is observable even within national borders, in federal systems in which the individual regional entities have substantial powers to design and impose their own Laws. Whether this diversity is an important obstacle to the formation and flourishing of a vigorous unified market is a different matter, and one which can receive different answers from a theoretical perspective, and should addressed essentially as a contingent and empirical issue.

In all likelihood, harmonized rules in Contract Law would contribute to produce a reduction in complexity and disparity, and this, in turn, would produce some gains for the internal market, and thus for the participants in it -the European consumers as the ultimate beneficiaries. These gains would reveal themselves both in a static and in a dynamic way. Thanks to the pioneering contribution of Ronald COASE ${ }^{5}$ on transaction costs we know that transaction costs are real and important costs that prevent economic agents from taking the most efficient actions, and reaching the socially desirable outcomes. In many settings, that they are not subordinate in importance to technological or other more tangible costs. If a given measure brings about a decrease, greater or smaller, in the existing level of transaction costs involved in cross-border contracting, that measure actually entails a reduction of real costs for the economy and society, which implies a direct and tangible social benefit. These benefits may be difficult to assess and quantify, and their true extent may never be accurately determined, but the benefits would be real nonetheless. Also, who would, in the end, benefit more from this reduction in transaction costs depends upon market structure and the elasticity of demand for the different goods and services experiencing the diminution in transaction costs.

Moreover, this reduction of transaction costs of cross-border contracting between firms and consumers is very likely to produce also additional dynamic gains. Transaction costs created by legal heterogeneity erect barriers to entry in national markets for foreign firms, so a decrease in the former imply an enhanced chance of entry, and thus, increased competition within each of the national markets facing entry of foreign firms. And, as is well-known from standard economic theory, most gains from increased competition finally accrue to consumers.

The perspective of consumers is of course important, and not just for the reason that many of the static and dynamic gains of reducing costs for firms in engaging in cross-border transactions and activities ultimately result in the benefit of the consuming public. Consumers also face

\footnotetext{
5 See, for a summary of his contributions and thinking in this field, Ronald COASE, The Firm, the Market and the Law, University of Chicago Press (1990).
} 
transaction costs in cross-border trade, and these are also real economic costs, whose reduction would also bring both static and dynamic gains. The additional problem here is that the perceptions of consumers on the real importance of diversity, and the extent of the reduction brought about by the harmonized rules are, with high likelihood, less accurate than those of firms. Hence, even if a real reduction in legal diversity -and legal uncertainty associated with the legal diversity- in cross-border transactions has taken place, if consumers are slow, or myopic, in evaluating the new situation, purely perceived or imaginary -but effective nonetheless, heretransaction costs would remain at the previous high level, and little would be gained by the adoption of harmonized rules.

In short, in order to exploit the advantages -real ones, not imaginary- of harmonized rules in Contract Law, the reduction in diversity and the enhanced certainty needs to be internalised by the agents subject to the rules, by the potential contracting parties. Otherwise, transaction costs may persist, even when the basis for them has now largely evaporated.

\subsection{Economies of scale in legal reform}

The third potential benefit of a European process of producing a new body of Law in the field of contracts is of a different nature. It has to do mainly with the costs of Law-making. Careful, knowledgeable, and effective law-making is by no means an inexpensive activity. Let's imagine a benevolent Law-maker desiring to improve the welfare of those concerned by a given set of Laws and regulations. In order to aptly carry out this goal, our Law-maker would need:

(i) to collect reliable evidence on the actual state of the events one desires to regulate;

(ii) to consider some range of alternatives for each issue under consideration;

(iii) to estimate the likely impact of the regulatory alternatives on the position of the relevant individuals and groups;

(iv) to draft the Law, and legal drafting may be costly depending on the kind and length of the exercise;

(v) to invest political capital to convince the relevant public of the virtues of the new legislation, and to overcome opposition from the interest group who may be harmed by the legal reform, even when overall it enhances social welfare.

All those preparatory activities for the legal reform to be designed, drafted and passed -and I am abstracting here from implementation and enforcement issues- are costly. And a significant fraction of those costs are invariant to the number of individuals and firms that will benefit from the new legal regime. Part from those costs would not vary much if the Law will be adopted in a jurisdiction with a population of 1 million, or in another with a population of 100 million. That is, there are important monetary and non-monetary fixed -in the sense of population-invariantcosts of Law-making.

And fixed costs allow for economies of scale, meaning that if production is concentrated to serve a larger population, the per-capita costs of production decrease. Thus, a legal reform that may not be cost-effective if needed to be adopted separately by each Member State, may be cost-effective if adopted at the European level, given that for the same -assumedly, at least- level of benefit in 
terms of increased social welfare, the costs of adopting the measure are now lower due to the increased scale that produces significant savings.

This gain of European law-making may be even stronger if one thinks of a large and complex body of the Law, such as Contract Law. The breadth and complexity of the subject matter probably make those costs of Law-making (think of political capital, for instance) grow more than proportionately.

\section{The potential costs of adopting harmonizing instruments on European Contract Law}

From an economics perspective, the common theme in debates about legal, regulatory or institutional harmonization is the issue of regulatory competition as a competitive alternative to top-down harmonization or rule-setting. In the most naïve version of this model, Contract Law (or Law and regulations in general) is a public good, and the beneficiaries (the main ones being the contracting parties in our case) would move (not necessarily in physical terms, it can be virtually by opt-in or choice of Law clauses) towards the most desirable set of rules providing the maximum available welfare for themselves. Governments, wishing to attract more parties to their own jurisdiction, would strive to achieve the best possible set of rules in order to maximize entry -and presumably revenue- by users of their sets of legal rules and regulations. Of course, topdown harmonization would interfere with the process that allows this desirable competitive equilibrium to emerge. The most familiar example of this kind of competitive process that the believers in the practical relevance of the regulatory competition model usually pose as an example, is that of Corporate Law evolution in the US. This body of Private Law is characterized and described by many as the product of healthy competition by different US states offering menus of default rules of Corporate Law that would induce firms to incorporate in that state, and thus increase the tax revenue from incoming firms ${ }^{6}$.

The regulatory competition models do not lack merit in general, and one should derive lessons from them, specially for the allocation of powers in multi-level governance scenarios, such as federal states, or the European Union7. A different matter is to trust that it can explain the

\footnotetext{
6 See, Roberta RomAnO, "Law as a Product: Some Pieces of the Incorporation Puzzle", Journal of Law, Economics $\mathcal{E}$ Organization (1985), p. 225. Many do not share the idea that such a competitive market exists: Marcel KAHAN and Ehud KamaR, "The Myth of State Competition in Corporate Law", Stanford Law Review (2002), p. 679. Mark ROE, “Delaware Competition", Harvard Law Review (2003), p. 588.

7 See, Robert CoOTER, The Strategic Constitution, Princeton University Press (2000), p. 130. For instance, and important implication -also for legal rule-making, and applicable to Contract Law- is that if there are competitive forces in provision of a public good, if mobility cannot affect one of the providers (for instance, the federal Government, in a Federal State, or the European institutions, in the European Union), because it is located at a higher level than the rest, that player should not enter the race of providing it competitively -it may supplement, or replace other kinds of provision, or encourage the adoption of common standards or model rules- with respect to the others, because this will lead to overprovision (in the case of Law-making, too much, and too expensive, Law). This may be an initial theoretical reason to not to favor an optional -in competition with existing national Laws- general instrument on European Contract Law, although the specifics of the context in which this
} 
evolution of Private Law (or legal rules in general) in multi-jurisdictional contexts. I will not deal in detail with the reasons that should lead us to be more parsimonious about the predictive power of regulatory competition models in Law and legal institutions. I will, however, sketch three reasons for my -relative and, I think, healthy- skepticism.

First, such models ${ }^{8}$ pose very strong assumptions on relevant variables, and most of all, on the goals of the main Governmental players. What the goals of politicians sponsoring and passing a given piece of legislation are, is difficult to synthesize in one objective function: Maximize social welfare?; maximize tax revenue?; why not simply voters' support -and foreign users of the public good will not be voters- or other political goals? Moreover, in legal matters, Courts are also very influential players in creating and enforcing the rules, and they may -and typically have- very different goals from those that elected politicians typically have. Assumptions about information and mobility costs and gains, both for users and providers of the rules, and concerning the characteristics of the relevant populations, are crucial, and the results will be very sensitive to changes in them.

Second, that the results in some areas in which regulatory competition models have been more thoroughly explained, such as environmental standard-setting, have led to relatively inconclusive results about the nature and welfare properties of the equilibria. In some scenarios we observe a kind of race to the bottom, but under other assumptions the level of stringency of regulatory standards increases under regulatory competition. ${ }^{9}$ Empirical evidence, although not entirely lacking, is not conclusive enough to derive potent predictions about the expected outcomes. ${ }^{10}$ The welfare effects in another important, and well-researched area, such as tax, are also not determinate. ${ }^{11}$

Third, that the outcome of the competitive race is not independent of the relative power of the groups that may actually benefit, or to the contrary, be harmed by the existing rules or by the introduction of new rules. Competition may thus occur along certain dimensions that do not prejudice the gains from the most powerful or organized group, but will not take place over those dimensions of the legal regime that could risk the benefits of the statu quo for the most

competitive process and the incentives for the competitors - what would be the advantages of the European Union of attracting contracting parties?- would require further analysis.

8 They all follow the initial and pioneering contribution on competition in local public goods provision by Charles TiEbout, "A Pure Theory of Local Expenditures", Journal of Political Economy (1956), p. 416. The so-called TiEBOUT hypothesis (that efficiency in the provision of local public goods can be achieved by competition and sorting) has contradictors, however: See, Truman BEWLEY, "A Critique of Tiebout's Theory of Local Public Expenditures", 49 Econometrica (1981), p. 713.

9 See, for instance, Scott BARRETT, "Strategic Environmental Policy and International Trade", Journal of Public Economics (1994), p. 325, with effects that depend on whether firms compete à la Cournot or à la Bertrand.

10 See, Yuquing XING and Charles KolstAD, “Do Lax Environmental Regulations Attract Foreign Investment?”, Environmental and Resource Economics (2002), p. 1.

11 See, for a summary of the literature, Jean HINDRIKS and Gareth MYLES, Intermediate Public Economics, MIT Press (2006), p. 569. 
influential groups in the relevant sector or situation. This is how more recent models of Corporate Law evolution characterize the US "competitive market" in Corporate Law rules, in which competition is shown to produce optimal rules with respect to issues that do not have a substantial effect on management's private benefits, but not with respect to issues that have such an effect ${ }^{12}$.

All in all, in order to have a balanced view of legal harmonization issues, and of the current European process on Contract Law, I am not entirely convinced that opposing arguments based on regulatory competition should carry the most weight. I think there are other sources of concern.

\subsection{Heterogeneity of preferences and economic conditions}

It is hard to deny that European societies and economies are diverse both in terms of preferences by citizens on many issues, and also in levels of wealth and distribution of that wealth among different societal groups.

And Contract Law, specially in what is the large bulk of it -namely, default rules to complete the contract in the way in which the parties' welfare and thus contract surplus would be maximizedshould be concerned about what the majority preferences of the potential contracting parties about the contractual solutions they would choose if they had written a completely contingent contract. This does not mean that default rules should always be majoritarian in this sense, because optimal default rules, in scenarios of asymmetric information could well be countermajoritarian in order to efficiently elicit information from the party that enjoys the informational advantage. ${ }^{13}$

It is apparent that, in the current European context, it is far from clear that a uniform ${ }^{14}$ panEuropean content of the chosen rules would be optimal for the conditions of all national markets, and the various societal preferences concerning desired solutions to the incentive problems in Contract Law, given its very wide coverage of transactions and agents whose behavior will be affected $^{15}$. One must concede that even under some new European body of Law in the contractual sphere, individuals and firms would not be subject across Europe to exactly the same

12 See, Oren BAR-GILl, Michal BARZUZA and Lucian BEBCHUK, "The Market for Corporate Law", Journal of Institutional and Theoretical Economics (2006), p. 134; Fernando GómEZ and Maribel SAEZ, "Competition, Inefficiencies and Dominance in Corporate Law", Journal of Institutional and Theoretical Economics (2006), p. 161.

13 See, on these two kinds of default rules in Contract Law, Ian AYRES and Robert GERTNER, "Majoritarian vs. Minoritarian Default Rules", Stanford Law Review (1999), p. 1591. Not everyone interested in the theory of optimal default rules agrees with the existence of information-eliciting default rules: Eric POSNER, “There Are no Penalty Defaults in Contract Law", 33 Florida State University Law Review (2006), p. 653.

14 On similar issues concerning rules protecting consumers from commercial practices by firms, see Hans-W. Micklitz, 'A General Framework Directive on Fair Trading', in H. ColLINS (editor) The Forthcoming EC Directive on Unfair Commercial Practices, Kluwer (2003), p. 75-76.

15 Similarly, for consumer Law, see Geraint HowELLs, 'The Scope of European Consumer Law' European Review of Contract Law (2005), p. 367. 
set of requirements and rules of conduct. A brief look at the Draft CFR, as well as simple reflection on the current formulation of many Contract Law rules, shows that general clauses and standards which allow ample room for interpretation and judgement in accordance with the specific circumstances of the national and/or product market affected, and thus, permit a relatively wide variety of substantive outcomes abound. The enforcement of the rules will also be left to the Courts and legal procedures of the Member States, reflecting a large range of legal cultures, traditions, organizational modes and enforcement strategies, thus keeping a very significant source of variety in the real solutions implemented in the different countries.

Despite these loopholes in the harmonisation effort, it is almost axiomatic (or else the entire process would be a wasted endeavor) that uniformity of substantive outcomes in regulating contractual behavior would increase, perhaps substantially. And this uniformity would imply a reduction -neutrally understood, not necessarily good or bad from the standpoint of efficiency, for instance- in the current levels of intervention on contractual matters in some countries. It would also imply an increase in such levels for other countries. If (a big if, however) the existing levels are roughly adapted to the market conditions in each country, and to the societal preferences towards solutions for managing contractual matters, such a move towards uniformity would entail costs and losses to the affected parties and to the European societies in general.

The second source of concern affecting the existing heterogeneity of circumstances refers to the disparate levels of wealth across European countries, and the different internal distributions of wealth and income within a given society, even for countries with roughly similar levels of GDP per capita. And Contract Law rules -private Law rules more generally- frequently set behavioural standards enforced through legal consequences in the form of a monetary transfer or payment (monetary damages). In such settings, it has been shown that the standards -even assuming the same level of social benefits from subjecting behavior to a given standard- should not be independent of the level of wealth of the group of people (or firms) subject to the standard, nor independent on how wealth is distributed among groups of potential infringers of the standard. Rules of this kind, thus, should be responsive to the economic conditions (both in terms of level and distribution of wealth) of the society in which they are imposed. Uniform rules equally adopted by different societies may not only fail to improve the current situation -for instance, the level of contract breach- but even make matters worse if the standard is maladapted to the true conditions of the relevant population ${ }^{16}$.

This should at least raise a strong note of caution towards uniform legal solutions in Contract Law (and in Tort Law even more clearly) that disregard existing diversity, not so much of legal traditions as the set of values and inherited notions of the legal profession, but as the basic economic conditions of the societies in which the rules are to be applied.

\footnotetext{
16 See Juan José GANUZA and Fernando GómEZ, "Realistic Standards: Optimal Negligence with Limited Liability" Journal of Legal Studies (2008) forthcoming.
} 


\subsection{Process goes beyond mere codification, for better and for worse}

The second source of concern reflects the actual design of the process as foreseen in the 2004 Commission Communication on European Contract Law and the revision of the Acquis. According to this roadmap the enterprise should go beyond mere codification of the existing EU formal legal rules affecting Contract Law, notably the consumer protection Directives that constitute the core of such existing set of legal rules. This is positive, because current EU Law is haphazard in terms of coverage of issues, in terms of how the subject matter of each rule is addressed, and often also in terms of the solutions offered. This is not surprising given the constraints on European legislative powers upon these matters, and also the intricacies, legal and, above all, political, of law-making activities at the European level. Mere codification or ordering of the existing rules may bring some benefits, in terms of legal certainty, technical precision and facility of implementation and interpretation in Member States, but it could hardly make a significant difference in the broad area of Contract Law at large.

In this respect, it is obvious that the process aspires to more ambitious results than simple systematization of the Acquis, and intends to reach areas that now are not covered, or only very thinly, by EU Law, and are firmly within the almost exclusive domains of national Private Laws. The reverse of these should be that EU Law does not deserve special status with respect to existing -in not yet harmonized areas- national Contract Law. The process should not treat the Acquis as sacred, and the approach, the structure, let alone the content of EU rules related to Contract Law should not condition the outcome of the process. Neither in scope -why not leave unregulated an area previously regulated, if that looks more desirable now after careful revision or analysis of the current circumstances and the effects of the existing regulatory scheme?- nor in content -why not alter the substantive solutions provided for in the past by the EU legislative powers if there are superior alternatives given the current state of the art in the field?

For instance, take the Commercial Agents Directive17, which substantially reflects the mideighties consensus between what was the legal treatment -of an even earlier origin- of commercial agents in France and in Germany, a consensus that is imposed by the Directive with mandatory nature over all contracting parties in these relationships. Distribution channels for goods and services have been much transformed in the past quarter century, and our knowledge of contracting practices has much increased in these years, thus making the normative solutions and the normative -mandatory- nature of the Commercial Agents Directive highly questionable ${ }^{18}$. Why in the process of harmonizing European Law should we treat the past normative choices as constraining our optimal choice in the present?

Paraphrasing the famous dictum of Justice Holmes against historical reasoning in the Law, there is nothing more revolting to justify a normative choice in the Law than to say that it was made in

\footnotetext{
17 Directive 86/653/EEC , on self-employed commercial agents, of 18 December 1986 on the coordination of the laws of the Member States relating to self-employed commercial agents (OJ L 382, 31.12.1986).

18 See, Fernando Gómez, “Compensation and Termination of Long-Term Distribution Contracts: An Economic Perspective of EU Law”, Working Paper, Universitat Pompeu Fabra School of Law and InDret (2007).
} 
the past, no matter whether this past is the Roman antiquity, Napoleonic France or 1980's Brussels. In this respect, from an efficiency perspective, the process, in order to achieve the potential gains mentioned in Section II above, should not be constrained per se by existing EU Law nor, for that matter, the current Laws of Member States. Those rules should be taken into account as reflecting -at least on paper; they do not eliminate the need of true empirical evidence on contract behavior in real-world interactions-, the current background and state of affairs, as well as regulatory alternatives already applied. To some extent at least, they can also serve as proxies for the expressions of preferences by the affected societies and populations -although with a grain of salt, they may also reflect inertia, path-dependence, or the power of given interest groups. But they should not set the boundaries neither of the analytical task underlying the process, nor the possible substantive outcomes that may constitute their end product.

\subsection{A complex game in which legislator interacts with contracting parties and Courts}

In the process of legal reform one should always take good notice of the fact that, commonly, whoever drafts the rules -typically elected politicians in legislatures- is rarely in charge of interpreting and enforcing those rules. At least in the field of Contract Law, Courts play the largest role in interpreting and enforcing Contract Law, although in areas that affect consumers, or at least the collective interests of consumers, regulatory agencies do also have important interpretive and enforcement functions. An how Courts would perform such a role directly influences the real consequences and effects that the rules would have on the behavior of the parties that one wishes to regulate or affect. In this respect, legal rules are not the linguistic materials, the words and sentences in codes or other legal texts, but the way in which they are actually interpreted and enforced in real-world interactions. The latter may contribute to the goals pursued by the legislative bodies, but it may well work in the opposite direction, and render moot the incentives contained in the rules or, even worse, it may lead to unintended and undesired effects upon real world behavior. Thus, substantive Law cannot be designed in isolation and independently of the interpretive and enforcement institutions. They are joint inputs for the production of legal outcomes, and thus joint consideration is crucial for a thoughtful redirection in a given area of the Law ${ }^{19}$.

This is particularly true when one deals with harmonization of substantive rules that will end up in very diverse institutional settings for their interpretation and enforcement, a characterization that seems to fit well the environment corresponding to the current situation concerning Contract Law across European countries. Even if one assumes that Court organization and the interpretive strategies of Courts in Civil Law countries are roughly similar (a big if), the number, resources, and effectiveness of Courts are dramatically different across Member States. Moreover, procedural Laws are also very different, even within Civil Law systems, thus adding much to the heterogeneity. And this, even disregarding the still deeper differences that exist with respect to Common Law countries and jurisdictions.

\footnotetext{
19 Two very recent books deal with the importance of these factors for understanding how Laws are applied and, in the end, what is the impact of a legal system upon society: Richard POSNER, How Judges Think, Harvard University Press (2008); Einer ElHAuge, Statutory Default Rules. How to Interpret Unclear Legislation, Harvard University Press (2008).
} 
This does not imply that any harmonization effort in an environment of heterogeneous interpreting and enforcement institutions is doomed to failure. It may overall be a success, but it needs to anticipate how the variety of institutions will likely respond to the new rules, and choose among the substantive alternatives those that, given the anticipated interpretive and enforcement strategies by Courts, would produce overall the most preferable outcomes. It may lead, given such variety, to a preference of menus of solutions instead of single solutions for each issue, thus allowing for a better match between the substantive rule and the strategy to interpret or apply it (more or less formalist, or more or less distributivist, etc.).

One dimension that should not be underestimated is that, whatever its appearance, Contract Law in Europe is de facto judge-made Law, even in the countries with codified provisions on general Contract Law and particular types of contract. One reason for this feature is that the written rules in Contract Law tend to be old rules, in the sense of rules that have been around for some time in that given legal system. In some countries, they are directly or indirectly from the codification period, and even their substantive content may be traced back to the XVIII century, or to Roman Law. That gives them, regardless of their textual appearance, some degree of open-textured character, and invites typically more creative (or aggressive, if one prefers) and less formalistic interpretive strategies, at least in view of the need to take into account the passage of time and the necessary adjustment to new circumstances. New written Laws, at least in Civil Law judicial traditions, seem to invite less risky interpretive strategies, and more formalistic approaches. This difference needs to be considered in every process of legal reform.

Another related dimension that seems relevant is the context-dependent desirability of many rules and solutions in contractual environments. Traditionally, most rules in Contract Law are characterized by a high degree of abstraction. In Civil Codes, even the rules on specific kinds of contract tend to be of an abstract nature, because they apply to virtually all contracts of a given kind, regardless of the particular object of the transaction, and the circumstances that surround the contract and the contracting parties. More recent rules, such as those in the consumer Acquis, and the national Laws implementing them are less abstract in this respect, although they still are -as they are bound to be, no doubt- not fully aware of the whole range of elements that influence the transaction in a relevant way.

The economic literature on contracts, and in particular the branch dealing with incomplete contracting, has identified several dimensions of contractual interactions in different environments (spot contracts, long-term contracting, and so on) that affect the desirability of the most basic rules of Contract Law, such as remedies for breach of contract. For instance, for long-term contracts (such as those in distribution chains: agency, distributorship, franchising) some of the factors that affect whether and how one party should pay compensation to the other, say for early termination, include: The timing of the parties' interaction, the role of reputation to control opportunities for non-cooperative behaviour, the verifiability of instances of breach along the relationship, and the variance between different kinds of breach, the incentives to make investments in the relationship, particularly relation-specific investments, 
are but the most relevant that have a bearing on the desirability of the existence, scope, and nature of a compensation scheme ${ }^{20}$.

This illustration shows that rules in Contract Law should not be fact-invariant, or circumstance invariant. Their abstract character invites and allows further additional rule-making (essentially by Courts, eventually by other adjudicators) more adaptive to the particular circumstances of the economic interaction at hand. But this -unavoidable, if one wants to achieve desirable incentives for the contracting parties- delegation of rule-making powers to the adjudicators creates some degree of tension with the Pan-European harmonization goal. In any case, the latter should not lead to view abstract principles and rules, such as commonly found in Contract Law, as requiring a uniform solution across diverse economic circumstances and scenarios. Otherwise, the exercise will be recipe for unresponsive legislation.

In Contract Law, moreover, we encounter additional players. Contrary to other areas of the Law, the contracting parties themselves, under freedom of contract, which is a basic principle of European Contract Laws, can respond to the rules (at least if they are default rules) and to the interpretive and enforcement strategies by Courts by altering the contracts they write. They can write more detailed contracts, or they can alter their content, to avoid, or to otherwise adapt, to the new rules. This needs to be carefully considered when drafting rules and interpreting them. Some normative choices, for instance, may be undone by the parties, and at the expense of additional transaction costs.

It has long been observed that incompleteness in contracting may well not be the product of nonvoluntary constraints affecting the parties or the general contracting environment (cognitive deficiencies, unverifiability, informational deficits). It can be a chosen strategy by the parties at the contracting stage to increase their expected welfare from the transaction. For instance, the parties may consider advantageous, under certain circumstances, to rely on internal (including reciprocity-based) motivators for cooperation over external mechanisms such as formal and legally enforceable contracts, and thus use only very simple contracts. To force upon those parties who choose such contracts, for instance, a very detailed set of default rules, would only trigger more detailed -and costly- contracts in response, and even some weakening of the non-legal motivators set in motion by the parties.

The interaction between contractual choices of the parties and Court enforcement, under the shadow of the default rules seems to be how to best understand the operation of contracting and Contract Law. In fact, an important strand of the Law \& Economics literature considers the issue of vagueness in contract language and directives, and the reaction from Courts in the face of the chosen level of contract texture and precision, as one of the central issues of Contract Law ${ }^{21}$. The

\footnotetext{
20 See, Fernando GómEz, "Compensation and Termination of Long-Term Distribution Contracts: An Economic Perspective of EU Law", Working Paper, Universitat Pompeu Fabra School of Law and InDret (2007).

21 See, Alan SchwARTz, "Relational Contracts in the Courts: An Analysis of Incomplete Agreements and Judicial Strategies", Journal of Legal Studies (2002), p. 271; Richard POSNER, "The Law and Economics of Contract Interpretation", Texas Law Review (2005), p. 1581; Robert SCOTT and George TRIANTIS, "Anticipating Litigation in
} 
common starting point of this literature is the observation that, even among commercially sophisticated parties, informality (contracts may not be in writing, or when they are, their content is sketchy), vagueness (commonly only something very obligationally incomplete has been agreed) and open-endedness prevails. The earlier fraction of these studies, essentially normative in spirit, dealt with the identification of the optimal default rules and interpretive strategies that Courts should adopt in the presence of contract vagueness (presumably, or at least assumedly, due to exogenous factors).

More recently vagueness has been fully and explicitly considered (as it should be) as a chosen strategy by contract parties in response to contract enforcement and adjudication by Courts -and the likely imperfections that may afflict them. This analysis, however, has just started, but it points out -albeit with still indeterminate results- at an issue that is crucial for law-making and Court behavior in the area of contracts.

\subsection{The lack of clear behavioral models on contracting behavior}

Contract Law, as any other area of the legal system, tries to affect, in the desired direction, the behavior of those subject to its rules. Thus, in order to give adequate structure and content to a new set of rules at the European level that will have some influence on European citizens and firms, one would need some estimate of how the latter would likely respond to the rules. This estimate, in turn, requires some kind of -at least implicit- model of how firms and individuals behave in the contracting sphere and whether this model seems to be sufficiently confirmed by the available empirical evidence of actual behavior by contracting parties or other agents in a similar situation.

In this respect, the current process seems to be lacking both in terms of a clear expression of the models that will guide the estimates about the likely effects of the newly adopted rules, and in the empirical validity of those models.

For instance, a substantial part of the harmonization effort will affect contracts between firms and consumers. Some sort of general understanding of consumer behavior must underlie the choice among different regulatory alternatives (in terms of general or individualized information disclosure, of cooling-off periods, of enforceability of penalty terms, just to mention a few examples). The reference, such as that made by the Unfair Commercial Practices Directive ${ }^{22}$ to the existing case-Law of the ECJ, and to the notion elaborated by the Court of the average consumer, who is the one reasonably well-informed and reasonably observant and circumspect, taking into account social, cultural and linguistic factors, does not seem to provide a clear benchmark to estimate the effects of the different choices upon the future behavior by consumers.

Contract Design", Yale Law Journal (2006), p. 814; Albert CHOI and George TRIANTIS, "Completing Contracts in the Shadow of Costly Verification", Working Paper, University of Virginia School of Law (2007) (available at SSRN: http://ssrn.com/abstract=958752).

22 Directive 2005/29/EC, of the European Parliament and of the Council, concerning unfair business-to-consumer commercial practices in the internal market (OJ L 149, 11.6.2005). 
Neither the Commission Communication, although this is not surprising, given the character of the document, nor the Draft CFR contain an explicit or implict general model of behaviour expected from the agents subject the principles and rules. A plausible one, and even a likely one, given the good reception that such accounts of human behaviour have encountered among many lawyers at the other side of the Atlantic, is that of behavioral economics, or behavioral Law and Economics. The approach adopted in the Draft CFR does not make direct reference to it, nor is it even traceable that it generally underlies the choices made by the drafters, even when paternalist policies are proposed ${ }^{23}$.

The most theoretically oriented (or, as it turns out, also the most empirically oriented) among the drafters of a new body of principles and rules in Contract Law could have tried to find such a model of human reaction to Law and legal institutions in the extensive experimental literature by psychologists and economists showing that human beings, when making choices of very diverse nature and scope, are subject to a number of behavioral biases. In laboratory settings it has been well documented that some phenomena ${ }^{24}$ repeatedly appear in observed behavior. People seem to show bounded rationality, that is, limited capacity to acquire and process information, as revealed by the use of cognitive heuristics that can lead to judgement errors, such as the hindsight bias -attaching over-dimensioned likelihoods to events that have actually occurred; the availability heuristic -excessive reliance on easily available data-; the representative bias -excessive representativeness of small samples. Other important expressions of bounded rationality experimentally identified have to do with time inconsistency or hyperbolic discounting -too little weight of future and uncertain events- and over-optimism on the part of the agents -underestimation of probabilities of bad outcomes affecting them. There are other sources of departure in observed behavioral responses from the axioms of expected utility in the neoclassical sense, such as loss aversion -the overweight awarded to losses from the starting point as compared to missed opportunities to gain-, the endowment effect -valuation of an asset depending on the set of entitlements known by the agent-, and the statu quo bias -reticence to alter the existing state of the world due to attaching some unidentified intrinsic value to it.

To formulate a model, however, even a model that is evidence-based, and not merely speculative, is not enough. To be taken seriously for policy-making, and for legal policy-making even more, this model has to be confirmed by evidence. Even if one takes the magnitude and relevance of the experimental findings relative to those behavioral biases for granted, as I do ${ }^{25}$, there is-at least at

\footnotetext{
${ }^{23}$ It must be said, however, that traditional paternalist legal interventions are not necessarily the legal ally of behavioral accounts of human conduct: Colin CAMERER, George LOEWENSTEIN, Samuel ISSACHAROFF, Ted O'Donoghue, and Matthew Rabin, "Regulation for Conservatives: Human Decision Making and the Case for Asymmetric Paternalism", 151 University of Pennsylvania Law Review (2003), p. 1211.

24 See, among many surveys helpful for legal audiences, Cass SUNSTEIN (ed.), Behavioral Law and Economics, Cambridge University Press (2000); Christine Jolls and Cass SUNSTEIN, “Debiasing through Law”, Journal of Legal Studies (2006), p. 199.

25 Albeit not all do, even among experimental economists: Elizabeth HoFFMAN, Kevin McCABE, Keith SHACHAT, and Vernon SMith, "Preferences, Property Rights and Anonymity in Bargaining Games", Games and Economic Behavior (1994), p. 346; Charles PlotT, and Kathryn ZeILER, “The Willingness to Pay-Willingness to Accept Gap,
} 
the present state of knowledge- no good reason to adopt as a general model of consumer behavior -or contracting behavior more generally- the one based on biased and bounded rationality, instead of the rationality model commonly used by Economics and Law and Economics.

The reasons for this -at least provisory- skepticism are of a varied nature. First, because one thing is to identify some bias in a laboratory setting, even repeatedly, a very different one is to test the statistical significance of such bias on real-world markets using rigorous empirical techniques. And even if the empirical tests do not confirm the implications of the rationality assumption, this by itself is not an empirical confirmation of the behavioral account, given that the data may be influenced by some other unobserved variable.

Several empirical studies have tested some of the implications of bounded rationality models of consumer behavior in different settings, and have not found empirical support for the hypothesis based on the pervasive presence of certain behavioral biases in such consumer markets ${ }^{26}$ : credit card markets, testing for (i) evidence of highly borrowing consumers paying higher interest rates but enjoying low introductory teaser rates27; (ii) the true causal factor behind the correlation between credit card debt and filings for personal bankruptcy 28; (iii) the factors explaining the "Borrow High Lend Low" Puzzle29; standard form contracts, and testing for evidence of competitive pressures decreasing quality of non-salient or hidden terms ${ }^{30}$; allocation of shelf space in supermarkets, and testing whether it is a result of manipulation by retailers of cognitive biases afflicting consumers, or else responds to manufacturer margins for different lines of products $^{31}$; choice of calling plans when different pricing options are introduced ${ }^{32}$.

the Endowment Effect, Subject Misconceptions and Experimental Procedures for Eliciting Valuations", American Economic Review (2005), p. 530.

26 A good summary of such studies, in Joshua WRIGHT, "Behavioral Law and Economics, Paternalism and Consumer Contracts: An Empirical Perspective", New York University Journal of Law \& Liberty (2007), p. 470.

27 See, Tom BROWN and Lacey Plache, "Paying with Plastic: Maybe Not so Crazy", University of Chicago Law Review (2006), p. 77, finding no evidence of hyperbolic discounting.

28 See, Todd ZYwICKI, Bankruptcy and Personal Responsibility: Bankruptcy Law and Policy in the Twenty-First Century, Yale University Press, (2007).

29 The puzzle refers to the observation that many people borrow on their credit cards -at high interest rate- while holding positive balances on their accounts -yielding no or little interest: David GROSS, and Nicholas SOULELES, "Do Liquidity Constraints and Interest Rates Matter for Consumer Behavior? Evidence from Credit Card Data" Quarterly Journal of Economics (2002), p. 149. Nadia MASSOUD, Anthony SAUNDERS, and Barry SCHOLNICK, "Who Makes Credit Card Mistakes? University of Alberta and NYU Working Paper (2006) find that traditional demographic (age, educational level, country of origin if immigrant) and economic variables (income) seem to be the major factors explaining the puzzle, and not intrinsic human biases.

30 See, Florencia MARotTA-Wurgler, "Competition and the Quality of Standard Form Contracts: An Empirical Analysis of Software License Agreements", Working Paper, New York University School of Law (2005).

31 See, Benjamin KLEIN and Joshua Wright, "The Economics of Slotting Contracts", Journal of Law and Economics (2007). 
There are, of course, a number of serious empirical studies showing how data on actual behavior in a given consumer market seems to give support to the presence of a certain behavioral bias as an important factor behind observed patterns of market behavior. Among others, such studies include evidence with respect to: (i) credit card markets and hyperbolic discounting ${ }^{33}$; (ii) fitness club markets and time-inconsistent preferences with unsophisticated consumers who cannot selfrealize their own time inconsistency ${ }^{34}$; (iii) internet purchases of computer equipment using price search engines and consumer myopia concerning hidden terms and attributes ${ }^{35}$.

The sensible response to this apparently conflicting set of pieces of evidence is not to weigh it in a sort of purely quantitative fashion, but to conclude, at least tentatively, that the evidence is still inconclusive regarding the real world impact in consumer markets of many of the behavioral biases present in laboratory settings. Arguably it should lead us to consider that there is no single answer empirically satisfactory for the entire range of biases and for the entire set of circumstances and markets in which consumers may exhibit those biases.

The second reason lies in the power of learning. Consumers and non-professional contracting parties in general, as human beings are often not fully rational, are in fact clouded by cognitive and other biases that lead them to make mistakes, not only in laboratories and experiments conducted by researchers, but also in real life, and concerning actual market interactions. People learn from their prior mistakes, however, because they possess good feedback mechanisms that allow them to be aware of the consequences of mistakes, and induce them to avoid the same errors in later rounds of trade or future market interactions. Given that their own pockets sometimes, their own life and limb- are at stake, the incentives to draw lessons from past mistakes, and to improve performance in later transactions are powerful and effective ${ }^{36}$. The likelihood of learning taking place and being effective in eliminating the negative consequences of bounded rationality features is greater the more standardized the product or service (thus allowing learning not only from past own experience, but also from other consumers' experience) and the higher the routine nature of the transaction. Learning by consumers is important not just

32 See, Eugenio Miravete, "Choosing the Wrong Calling Plan? Ignorance and Learning", American Economic Review (2003), p. 297.

33 See, David Gross, and Nicholas Souleles, "Do Liquidity Constraints and Interest Rates Matter for Consumer Behavior? Evidence from Credit Card Data", Quarterly Journal of Economics (2002), p. 149; Haiyan SHUI and Lawrence Ausubel, "Time Inconsistency in the Credit Card Market", Working Paper, University of Maryland (2004); Stephan MEIER and Charles SPRENGER, "Impatience and Credit Behavior: Evidence from a Field Experiment", Working Paper, Federal Reserve Bank of Boston (2006).

34 See, Stefano Della Vigna and Ulrike Malmendier, "Paying not to Go to the Gym", American Economic Review (2006), p. 694.

35 See, Glenn ElLISON and Sara ElLISON, "Search, Obfuscation, and Price Elasticities on the Internet", Working Paper, MIT Department of Economics (2004).

36 See, Richard EPSTEIN, “Behavioral Economics: Human Errors and Market Corrections”, University of Chicago Law Review (2006), p. 111; Richard EPSTEIN, "Consumer Contracts: Behavioral Economics vs. Neoclassical Economics"An Exchange Between Richard EpSTEIN and Oren BAR-GILL, New York University School of Law", Law and Economics Working Paper, $n^{\circ} 91$ (2007). 
for the empirical relevance of behavioral biases in consumer markets, but also for the normative consequences of the observed level of their presence: if learning is to be expected, the benefits of a regulatory or legal intervention in the relevant market are lower, for a given initial level of biased behavior among consumers. Although conceptually different from learning, other kinds of consumer reactions to biases, such as developing personal rules to guide behavior precisely to counteract the former, may also lead to results that resemble those of learning ${ }^{37}$.

There is a substantial amount of empirical evidence showing that consumers learn from mistakes and improve their behavior in a wide range of consumer markets: credit card markets ${ }^{38}$, video rental markets ${ }^{39}$, telephone markets ${ }^{40}$. Still, of course, learning may take time, and may be costly, so I do not imply that consumer learning is a magic formula that would always restore markets to the functioning that full rationality and full information would characterize. In fact, it is clear that firms can interfere with learning processes of consumers through several means, and they would do so when it is in their interest to pursue that strategy, and the environment is able to sustain such shrouding behavior by firms. For instance, they can hide and make less accessible the elements of the transaction on which consumers are more likely to be misled about; they can create artificial non-standardization and product multidimensionality to retard and increase learning costs; they can engage in bundling to discourage learning and comparison shopping, they can engage in loss-leader tactics. Even in a non-bounded rationality environment, firms may engage in some of these tactics, to increase consumer search costs, but behavioral biases and learning may provide them with additional reasons for them. In sum, consumer learning does not eliminate the relevance of behavioral biases for consumer markets, but definitely recommends a more parsimonious attitude towards their magnitude and effects, and undermines a broad and indiscriminate translation of the experimental findings of the behavioral Law \& Economics literature into a general model of consumer behavior, let alone contract behavior by all individuals.

The preceding discussion shows that in order to adopt far reaching legal rules that would significantly affect the behavior of individuals and firms, consumers and professionals, in a myriad of settings and market and non-market interactions, as is foreseen in the current harmonization exercise of European Contract Law, we would be better-off, in theoretical terms, by having clear starting points in terms of our general understanding of how the agents will act under legal rules. And that there is a growing, though far from complete, amount of empirical

37 See, Roland BenAbou, and Jean Tirole, "Willpower and Personal Rules”, Journal of Political Economy (2004), p. 848; Dilip SOMAN, and Amar CHEEMA, "When Goals are Counterproductive: The Effects of Violation of a Behavioral Goal on Subsequent Performance", Journal of Consumer Research (2004), p. 52.

38 See, Sumit Agarwal, Souphala ChOMSISEngPhet, Chunlin LiU, and Nicholas Souleles, "Do Consumers Choose the Right Credit Contracts?", Working Paper, Federal Reserve Bank of Chicago (2006); Sumit AGARWAL, John Driscoll, Xavier GabaIX, David LaIBSON, "Stimulus and Response: The Path from Naïveté to Sophistication in the Credit Card Market", Working Paper, NYU Stern School of Business (2007).

39 See, Peter Fishman, and Devin POPE, “The Long-Run Effects of Penalizing Customers: Evidence from the VideoRental Market", University of California at Berkeley Department of Economics Working Paper (2005).

40 See, Eugenio Miravete, "Choosing the Wrong Calling Plan? Ignorance and Learning", American Economic Review (2003), p. 297. 
literature on real-life contracting behavior that we need to consider in order to confirm the choice of general model, and the likely effects of the legal measures.

3.5. The insufficient use of the empirical knowledge on contracting behavior

As the discussion in the previous sub-section also suggests, a clear theoretical -but empirically testable and tested- model of contracting behavior, as a benchmark against which to assess the contemplated legal solutions, is intimately connected with the empirical knowledge developed using widely accepted statistical techniques on data reflecting the real-world contracting practices of real-world contracting parties. Also in this respect, the process under way concerning Contract Law in Europe seems somewhat lacking in terms of the interest in the existing empirical knowledge of its subject matter. In order to understand the potential effects that the incentives posed by legal rules will have on the behavior of contracting parties, and, eventually, on the markets that link them, one should not disregard the amount of knowledge that has been accumulated in recent years on how real people interact in a variety of contractual settings. This does not mean that there is an Iron Law of empirical regularity that does not allow for the possibility of anticipating diverging sorts of behavior, or that our current level of empirical understanding is final and cannot be improved. Quite the contrary, there is still much to learn empirically about contracting behavior. But what we know is not irrelevant to assess legal solutions, and to craft them in the light of that knowledge.

And this body of empirical literature on contracts and contracting behavior is not limited to the area of consumer behavior. For instance, in the field of long-term contracting and production and distribution chains, there is also a large and varied set of empirical findings that allow us to better understand actual contracting practice, and to better discern the likely effects of alternative legal solutions ${ }^{41}$.

Just to provide an example: The DCFR contains rules on termination of long-term distribution contracts, such as commercial agency, franchise, and distributorship. The DCFR has been crafted with more than one eye on the regime introduced for commercial agents by the Commercial Agents Directive, even if the proposed rules simplify and clarify the complicated -due to the compromise between the then prevailing German and French approaches- regime in the Directive, essentially adopting the German perspective. Thus, as a general provision for such kinds of contractual arrangements, the DCFR foresees a solution (Art. IV.E.2:303, probably inspired by the general principle in art. 17.2.c) of the Commercial Agents Directive) imposing damages for termination for inadequate notice, trying to ensure essentially, that the agent obtains the benefit he or she would have enjoyed, had the notice period been complied with, and using the average benefit of past three years as the benchmark to assess that benefit. Art. IV.E.2:305, in turn, contemplates and indemnity for goodwill broadly consistent with art. 17.2. a) of the Commercial Agency Directive. This later indemnity is not mandatory -except for commercial agency, under the complex regime proposed in IV.E.3:312, in turn inspired by art. 17.2.b) of the Directive- but it would, unless otherwise agreed by the parties, be applicable also in favor of the

${ }^{41}$ See, a survey of this literature in Fernando GómEZ, "A Survey of the Empirical Findings on Production and Distribution Chains", Mimeo, Universitat Pompeu Fabra School of Law (2005). 
party who had breached the contract, even fundamentally, something that the Commercial Agents Directive explicitly excluded in art. 18 (a) of the Directive. Moreover, Art. IV.E.2:304 prohibits all clauses that allow one party to terminate for instances of breach of the other party that are not cases of fundamental breach, thus making impossible to use termination as an effective tool to sanction instances of non-verifiable breach, a common occurrence in long-term, incomplete, and poorly specified contractual relationships as the ones prevailing in the field of distribution.

Those solutions restricting termination in this field of contracting (which, it must be noted, is not B2C, but B2B) seem to have been adopted without regard to the available empirical evidence that seems to support a much more parsimonious view of the beneficial effects of ad-hoc specific rules favoring one of the contracting parties ${ }^{42}$. The use of such relevant evidence should not be left to an outside, ex-post economic evaluation of the proposed legal solutions (although it should be part of it, as the role of the Economic Impact Group shows) but would be more fruitful if an integral part of the entire exercise. It is, buy all means, a good idea, to have an Economic Impact Group, to "provide a broad assessment of the economic implications of the rules taking into consideration the needs of economic operators in the internal market" 43 . But the role of theoretical and empirical knowledge, mainly of an economic bent, on contracting behavior, incentives and practices, could play a larger role in the process, contributing to the analysis that leads to crafting and evaluating the legal solutions.

In this respect, however, the current process of harmonization of European Contract Law does not seem to be making good -or enough, at best- use of existing knowledge, both theoretical and empirical, on the effects of incentives created by legal rules on behavior, even if one acknowledges, as I do, that this body of literature does not predetermine, in most respects, the desirability of most, let alone all, specific rules in Contract Law.

\footnotetext{
42 This literature has examined, using US data, the effects on actual behavior by franchisors and franchisees of legal measures restricting contract termination, and has found relevant evidence that the latter are reducing the level of use of franchise contracts that is not compensated with an increase in franchisor-operated outlets, thus creating a serious source of concern on the effects of such legal rules on the population of potential franchisees and also of potential employees of the outlets: See, James BRICKLEY, Frederick DARK, and Michael WEISBACH, "The Economic Effects of Franchise Termination Laws", 34 Journal of Law \& Economics (1991), p. 101; Jonathan KLICK, Bruce KOBAYASHI, and Larry RIBSTEIN, “The Effect of Contract Regulation: The Case of Franchising" (2007) George Mason Law and Economics Research Paper 07-03.

On the literature dealing with termination of long-term distribution contracts, a review of the empirical results in Fernando GómEZ, "Compensation and Termination of Long-Term Distribution Contracts: An Economic Perspective of EU Law", Working Paper, Universitat Pompeu Fabra School of Law and InDret (2007).

43 See, Filomena CHIRICO, and Pierre LAROuche, “CoPECL Draft Plan- Economic Impact Group”, Working Paper, Tilburg Law and Economics Center, Tilburg University (2006).
} 


\section{Conclusions}

One of the most important -if not the key one- lessons to be drawn from the already large body of economic literature ${ }^{44}$ dealing with legal origins and institutions is that institutional choice matters. And it matters a lot for the future development of a given society, definitely if we measure development with the standard measurement tools in Economics.

To change an important area of the Law, to incorporate a new design and content in a relevant area of the legal system is not a choice of only modest and technical consequences for the operation of a part of a legal system. Institutional and legal choice has important and long lasting effects. It is more than altering specific legal rules, it also goes into the organization of the legal system as such, and may also affect the beliefs, perceptions and shared values of the main players within that system, and of citizens as a whole. Fundamental institutional and legal choices are thus likely to influence in a fundamental way not only short-term economic and social outcomes in the directly affected field, but will continue to shape economic and social development for a long time.

Contract Law is a fundamental area of the Law in all European legal systems, not just because of its long history and tradition, but mainly due to its enormous scope and its foundational nature for many, if not most, areas of Private Law, and Law generally. Institutional choice at a large scale in Contract Law is not a trivial exercise, it is very serious business, and should be undertaken with all existing knowledge and all necessary caution. This is not, and should not be taken to be, an unqualified plea in favor of the statu quo, but simply as a reminder of the magnitude, relevance and likely impact of the task of harmonizing Contract Law in Europe.

\footnotetext{
44 For a very recent summary by the initiators of the legal origins literature, see Rafael LA PORTA, Florencio LÓPEZ DE SILANES and Andrei SHLEIFER, "The Economic Consequences of Legal Origins" Journal of Economic Literature (2008, forthcoming) (available at http:// papers.ssrn.com/sol3/papers.cfm?abstract_id=1028081). For an excellent survey of the economic literature on the effects of institutions on economic development, see Daron ACEMOGLU, Simon JOHNSON and James ROBINSON, "Institutions as determinants of Long-term Economic Growth", in Philippe AGHION and Stephen DURLAUf (Eds.), Handbook of Economic Growth, North Holland (2005).
} 


\section{References}

Daron ACEMOGLU, Simon JOHNSON and James ROBINSON, “Institutions as determinants of Longterm Economic Growth", in Philippe AGHION and Stephen DurLauf (Eds.), Handbook of Economic Growth, North Holland (2005).

Sumit AgArWal, Souphala ChOMSISENGPHet, Chunlin LIU, and Nicholas SOUleles, "Do Consumers Choose the Right Credit Contracts?", Working Paper, Federal Reserve Bank of Chicago (2006).

Sumit AgARWAL, John Driscoll, Xavier Gabaix, David LAIBSON, "Stimulus and Response: The Path from Naïveté to Sophistication in the Credit Card Market", Working Paper, NYU Stern School of Business (2007).

Ian AYRES and Robert GERTNER, "Majoritarian vs. Minoritarian Default Rules", Stanford Law Review (1999).

Oren BAR-GILL, Michal BARZUZA and Lucian BEBCHUK, "The Market for Corporate Law", Journal of Institutional and Theoretical Economics (2006).

Oren BAR-GILL and Richard EPSTEIN, "Consumer Contracts: Behavioral Economics vs. Neoclassical Economics - An Exchange Between Richard EPSTEIN and Oren BAR-GILL, New York University School of Law", Law and Economics Working Paper, no 91 (2007).

Scott BARRETT, "Strategic Environmental Policy and International Trade", Journal of Public Economics (1994).

Roland BenABOU, and Jean TiROle, "Willpower and Personal Rules", Journal of Political Economy (2004).

Truman BEWLEY, “A Critique of Tiebout's Theory of Local Public Expenditures", 49 Econometrica (1981).

James BRICKLEY, Frederick DARK, and Michael WEISBACH, "The Economic Effects of Franchise Termination Laws", 34 Journal of Law \& Economics (1991).

Tom BROWN and Lacey PlaCHE, "Paying with Plastic: Maybe Not so Crazy", University of Chicago Law Review (2006).

Colin CAmerer, George Loewenstein, Samuel Issacharoff, Ted O'Donoghue, and Matthew RABIN, "Regulation for Conservatives: Human Decision Making and the Case for Asymmetric Paternalism", 151 University of Pennsylvania Law Review (2003). 
Ronald COASE, The Firm, the Market and the Law, University of Chicago Press (1990).

Hugh COLLINS, "EC Regulation of Unfair Commercial Practices", in Hugh ColLINS (ed.), The Forthcoming EC Directive on Unfair Commercial Practices, Kluwer (2003).

Robert COOTER, The Strategic Constitution, Princeton University Press (2000).

Filomena CHIRICO, and Pierre LAROUCHE, "CoPECL Draft Plan- Economic Impact Group", Working Paper, Tilburg Law and Economics Center, Tilburg University (2006).

Albert CHOI and George TRIANTIS, "Completing Contracts in the Shadow of Costly Verification", Working Paper, University of Virginia School of Law (2007) (available at SSRN: http:/ / ssrn.com/abstract=958752).

Stefano Della Vigna and Ulrike Malmendier, "Paying not to Go to the Gym", American Economic Review (2006).

Einer ElHaUge, Statutory Default Rules. How to Interpret Unclear Legislation, Harvard University Press (2008).

Glenn ElLISON and Sara EllisON, "Search, Obfuscation, and Price Elasticities on the Internet", Working Paper, MIT Department of Economics (2004).

Richard EPSTEIN, "Behavioral Economics: Human Errors and Market Corrections", University of Chicago Law Review (2006).

Peter FishMAN, and Devin POPE, “The Long-Run Effects of Penalizing Customers: Evidence from the Video-Rental Market", University of California at Berkeley Department of Economics Working Paper (2005).

Juan José GANUZA and Fernando GóMEZ, "Realistic Standards: Optimal Negligence with Limited Liability" Journal of Legal Studies (2008) forthcoming.

Fernando GómEZ, "Contract Law and Economic Welfare: A View from Law and Economics", Stefan GRUNDMANN (ed.), Constitutional Values and European Contract Law, Kluwer (2008) (forthcoming).

--, "A Survey of the Empirical Findings on Production and Distribution Chains", Mimeo, Universitat Pompeu Fabra School of Law (2005).

-- "The Unfair Commercial Practices Directive: A Law and Economics Perspective", European Review of Contract Law (2006). 
-- "Compensation and Termination of Long-Term Distribution Contracts: An Economic Perspective of EU Law", Working Paper, Universitat Pompeu Fabra School of Law and InDret (www.indret.com) (2007).

Fernando GómEZ and Maribel SAEZ, "Competition, Inefficiencies and Dominance in Corporate Law", Journal of Institutional and Theoretical Economics (2006).

David Gross, and Nicholas Souleles, "Do Liquidity Constraints and Interest Rates Matter for Consumer Behavior? Evidence from Credit Card Data" Quarterly Journal of Economics (2002).

Stefan GRUNDMANN, "European Contract Law of What Colour?", (2005) 2 European Review of Contract Law.

Jean HINDRIKS and Gareth MYLES, Intermediate Public Economics, MIT Press (2006).

Elizabeth HoffMAN, Kevin MCCABE, Keith SHACHAT, and Vernon SMITH, "Preferences, Property Rights and Anonymity in Bargaining Games", Games and Economic Behavior (1994).

Geraint Howells, 'The Scope of European Consumer Law' European Review of Contract Law (2005).

Christine JOLLS and Cass SUNSTEIN, “Debiasing through Law”, Journal of Legal Studies (2006).

Marcel KAHAN and Ehud KAMAR, "The Myth of State Competition in Corporate Law", Stanford Law Review (2002).

Louis KAPLOW and Steven SHAVELL, "Why the Legal System is Less Efficient Than the Income Tax in Redistributing Income", 23 Journal of Legal Studies (1994).

--, "Should Legal Rules Favor the Poor? Clarifying the Role of Legal Rules and the Income Tax in Redistributing Income", 29 Journal of Legal Studies (2000).

Benjamin KLEIN and Joshua WrIGHT, "The Economics of Slotting Contracts", Journal of Law and Economics (2007).

Jonathan KLICK, Bruce KOBAYASHI, and Larry RIBSTEIN, “The Effect of Contract Regulation: The Case of Franchising" (2007) George Mason Law and Economics Research Paper 07-03.

Rafael LA PORTA, Florencio LÓPEZ DE SILANES and Andrei SHLEIFER, "The Economic Consequences of Legal Origins" Journal of Economic Literature (2008, forthcoming) (available at http:/ / papers.ssrn.com/sol3/papers.cfm?abstract_id=1028081). 
Florencia MAROTTA-WURGLER, "Competition and the Quality of Standard Form Contracts: An Empirical Analysis of Software License Agreements", Working Paper, New York University School of Law (2005).

Nadia MASSOUD, Anthony SAUNDERS, and Barry SCHOLNICK, "Who Makes Credit Card Mistakes? University of Alberta and NYU Working Paper (2006).

Stephan MeIER and Charles SPRENGER, "Impatience and Credit Behavior: Evidence from a Field Experiment", Working Paper, Federal Reserve Bank of Boston (2006).

Hans-W. MicKLITZ, 'A General Framework Directive on Fair Trading', in Hugh Collins (editor) The Forthcoming EC Directive on Unfair Commercial Practices, Kluwer (2003).

Eugenio MiRAVETE, "Choosing the Wrong Calling Plan? Ignorance and Learning", American Economic Review (2003).

Charles PlotT, and Kathryn ZEILER, "The Willingness to Pay-Willingness to Accept Gap, the Endowment Effect, Subject Misconceptions and Experimental Procedures for Eliciting Valuations", American Economic Review (2005).

Eric Posner, "There Are no Penalty Defaults in Contract Law", 33 Florida State University Law Review (2006).

Richard POSNER, How Judges Think, Harvard University Press (2008).

--, “The Law and Economics of Contract Interpretation", Texas Law Review (2005).

Karl RIESENHUbER, "System and Principles of EC Contract Law", (2005) 3 European Review of Contract Law.

Mark ROE, “Delaware Competition”, Harvard Law Review (2003), p. 588.

Roberta Romano, "Law as a Product: Some Pieces of the Incorporation Puzzle", Journal of Law, Economics \& Organization (1985), p. 225.

Alan SCHWARTZ, "Relational Contracts in the Courts: An Analysis of Incomplete Agreements and Judicial Strategies", Journal of Legal Studies (2002).

Robert SCOTT and George TRIANTIS, "Anticipating Litigation in Contract Design", Yale Law Journal (2006).

Haiyan SHUI and Lawrence AUSUBEL, “Time Inconsistency in the Credit Card Market”, Working Paper, University of Maryland (2004). 
Dilip SOMAN, and Amar CHEEMA, "When Goals are Counterproductive: The Effects of Violation of a Behavioral Goal on Subsequent Performance", Journal of Consumer Research (2004).

Alexander StREMITZER, "Opportunistic Termination", Working Paper, University of Bonn, Department of Economics (2007), available at SSRN: http:/ / ssrn.com/abstract=989557.

Cass SunsteIN (ed.), Behavioral Law and Economics, Cambridge University Press (2000).

Charles TiEBOUt, “A Pure Theory of Local Expenditures”, Journal of Political Economy (1956).

Yuquing XING and Charles KOLSTAD, “Do Lax Environmental Regulations Attract Foreign Investment?", Environmental and Resource Economics (2002).

Todd ZYWICKI, Bankruptcy and Personal Responsibility: Bankruptcy Law and Policy in the Twenty-First Century, Yale University Press, (2007). 